\title{
Anti-CD30 Antibody-drug Conjugate
}

National Cancer Institute

\section{Source}

National Cancer Institute. Anti-CD30 Antibody-drug Conjugate. NCI Thesaurus. Code C158973.

Any antibody-drug conjug ate (ADC) that is directed against the human tumor necrosis factor (TNF) receptor superfamily member 8 (TNFRSF8) CD30. 